\title{
Ureteral Obstruction in Endometriosis
}

\author{
Amit Mani Upadhyay, ${ }^{1}$ Ashok Kunwar, ${ }^{1}$ Sanjesh Shrestha, ${ }^{1}$ Kabir Tiwari, ${ }^{1}$ Hema Kumari Pradhan, ${ }^{2}$ \\ Ganesh Dangal ${ }^{2}$
}

'Department of Surgery, Kathmandu Model Hospital, Exhibition Road, Nepal,

${ }^{2}$ Department of Obstetrics and Gynaecology, Kathmandu Model Hospital, Exhibition Road, Nepal

DOI: http://dx.doi.org/10.3126/njog.v13i2.21712

ABSTRACT

Aim: Endometriosis is defined as functional endometrial glands and stroma that occur outside the uterine cavity. It is an estrogen dependent, benign, inflammatory disease that affects women during premenarcheal, reproductive and postmenopausal hormonal stages.

Methods: This is a retrospective review of six cases with diagnosis of ureteral endometriosis. All the patients were referred to Department of Surgery, Kathmandu Model Hospital and the study period was from September 2015 to August 2018.

Results: In our study all the patients had involvement of the ureter. All the patients who had undergone open surgery had extrinsic involvement of the ureter. Two patients wno had mild distal ureteric stenosis only were managed by diagnostic URS and retrograde DJ stenting. Another two patients with right distal ureteric stenosis were managed initially with retrograde DJ stenting but after removal of ureteric stent and in subsequent follow up the degree of hydroureteronephrosis increased in both the cases . These two patients were finally undergone right Lich Gregoir ureteroneocystostomy. In the remaining two patients, ureterorenoscopy (URS) guided double J stenting were attempted but failed to insert the stent due to stenosed ureter so they underwent open abdominal hysterectomy with excision endometriotic cyst with ureterolysis and double J stenting..

Conclusions: Ureteral endometriosis is a rare disease presenting most commonly with nonspecific symptoms and signs and thus making preoperative diagnosis often difficult for the clinicians. Treatment of ureteral endometriosis is primarily surgical. The surgical procedures which are usually performed are excision of all endometriosis lesion, ureterolysis, ureterectomy with ureteroureteral anastomosis and ureteroneocystomy.

Keywords: diagnostic ureteroscopy, endometriosis, ureterolysis, ureteroneocystostomy.

\section{INTRODUCTION}

Endometriosis is defined as functional endometrial glands and stroma that occur outside the uterine cavity. It is an estrogen dependent, benign, inflammatory disease that affects women during premenarcheal, reproductive and postmenopausal hormonal stages. It is typically located in the pelvis but can also occur at multiple sites like bowel, diaphragm and pleural cavity. Some patients with endometriosis are asymptomatic and those with symptoms can have varied and non-specific presentations and definitive diagnosis always requires surgery. So it is always challenging in determining prevalence of disease. Endometriosis is reported in up to $40 \%$ of adolescents with genital tract anomalies, $50 \%$ of women with infertility and $70 \%$ of women and adolescents with pelvic pain. ${ }^{1-3}$ The aim of our study was to evaluate the treatment outcomes of surgical management of ureteral endometriosis.

\section{CORRESPONDENCE}

Dr Amit Mani Upadhyay

Department of Surgery, Kathmandu Model Hospital,

Exhibition Road, Kathmandu, Nepal.

Email: amitmaniupadhyay@gmail.com,

Phone: +9779841281812

\section{METHODS}

This is a retrospective review of six cases with diagnosis of ureteral endometriosis. All the patients were referred to Department of Surgery, Kathmandu Model Hospital and the study period was from September 2015 to August 2018. Data were retrieved from the hospital records. Age of patients, mode of presentation, history of prior surgery, history of previous treatment received, modalities of radiological imaging performed, location and size of lesion, and final outcome of the definitive surgery provided were analyzed.

Patients diagnosed with ureteral endometriosis were included in the study. These patients were evaluated by routine urinalysis, urine culture and urine cytology along with routine hematological and biochemical parameters. Ultrasonography of abdomen and pelvis and contrast-enhanced computed tomography urogram (CTU) were performed in each case. Each patient underwent cystoscopy to rule out urinary bladder involvement. Three patients had undergone diagnostic ureterorenoscopy (URS) and retrograde double J stenting in the same setting. In two patients, 
intraoperative retrograde ureteropyelography (RPG) confirmed the level and degree of obstruction. Two patients undergone DTPA renogram study to assess the functional status of affected kidney. In one patient ultrasound guided percutaneous nephrostomy (PCN) catheter has to be inserted to relieve the obstructive uropathy.

The diagnosis of ureteral endometriosis was established by history and physical examination, radiological imaging, cystoscopy and ureteroscopy finding, intraoperative findings and final histopathological reports. The success of the treatment was defined by total improvement of symptoms and no recurrence of lesion and restoration of satisfactory renal function in the follow up period.

\section{RESULTS}

Age of the patients varied from 27 to 55 years with mean age of 38 years. Among 6 patients, one was postmenopausal. Two patients were married for less than three years with subfertility. Other parameters including mode of presentation, site of ureteric involvement, prior surgical history, definitive treatment received and follow up is illustrated in Table 1.

Table 1: Patient profile with treatment.

\begin{tabular}{|c|c|c|c|c|c|c|}
\hline S No & Age & $\begin{array}{l}\text { Presenting } \\
\text { symptoms }\end{array}$ & $\begin{array}{l}\text { Previous surgery/diagnostic } \\
\text { clue for endometriosis }\end{array}$ & $\begin{array}{l}\text { Site of } \\
\text { ureteric } \\
\text { involvement }\end{array}$ & $\begin{array}{l}\text { Definitive } \\
\text { Treatment } \\
\text { offered }\end{array}$ & $\begin{array}{l}\text { Follow up } \\
\text { ( months) }\end{array}$ \\
\hline 2 & 55 & Right flank pain & $\begin{array}{l}\text { 1.Excision of pelvic } \\
\text { endometrioma right side . 2.Rt } \\
\text { diagnostic URSand Dj stenting }\end{array}$ & Rt distal ureter & $\begin{array}{l}\text { Rt ureteric } \\
\text { reimplantation }\end{array}$ & 24 \\
\hline 3 & 31 & $\begin{array}{l}\text { Lower abdomen } \\
\text { pain }\end{array}$ & none & Left mid ureter & $\begin{array}{l}\text { TAH BSO } \\
\text { along with Lt } \\
\text { ureterolysis and } \\
\text { dj stening }\end{array}$ & 17 \\
\hline 5 & 27 & $\begin{array}{l}\text { Incidental } \\
\text { finding }\end{array}$ & Diagnostic laparoscopy & Rt distal ureter & $\begin{array}{l}\text { Diagnostic URS } \\
\text { and DJ stenting }\end{array}$ & 6 \\
\hline 6 & 38 & Rt flank pain & $\begin{array}{l}\text { 1.TAH LSO for intramural } \\
\text { fibroid. } \\
\text { 2.Rt diagnostic urs and } \mathrm{Dj} \\
\text { stenting }\end{array}$ & Rt distal ureter & $\begin{array}{l}\text { Excision of } \\
\text { chocolate cyst } \\
\text { and Rt ureteric } \\
\text { reimplantation }\end{array}$ & 28 \\
\hline
\end{tabular}

In our study all the patients had involvement of the ureter. None of the patients had involvement of urinary bladder. All the patients who had undergone open surgery had extrinsic involvement of the ureter. Three patients had involvement of right distal ureter, two patients had involvement of left ureter ( 1 mid ureter and 1 distal ureter) and one patient had involvement of both ureters.

Two patients who had mild distal ureteric stenosis only (Figure 1) were managed by diagnostic URS and retrograde DJ stenting (silicone stent) along with postoperative hormonal therapy. The stents were removed in 6 months and patients were evaluated three monthly by ultrasonography to see the degree of obstruction.

Another two patients with right distal ureteric stenosis were managed initially with retrograde DJ stenting but after removal of ureteric stent and in subsequent ultrasonogram and contrast enhanced CT study the degree of hydroureteronephrosis increased in both the cases (Figure 2 and 3). These two patients finally underwent right ureteric reimplantation (Lich Gregoir ureteroneocystostomy). In one case who had undergone Total Abdominal Hysterectomy with Left salpingoophorectomy (TAH+ LSO) in the past, during exploration compression of the distal ureter by a chocolate cyst was noted along with severe stenosis of right distal ureter. So excision of the chocolate 
cyst and right ureteric reimplantation (Lich-Gregoir ureteroneocystostomy) was carried out. Another post-menopausal lady, underwent Lich-Gregoir ureteroneocystostomy because of severe distal ureteric stenosis.

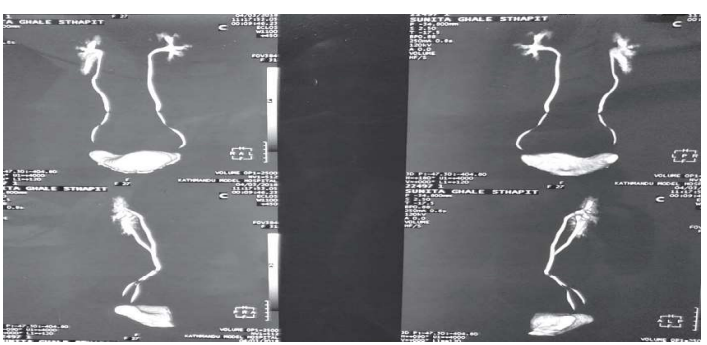

Figure 1: CTU showing mild Right distal ureteric stenosis treated by ureterscopic stenting.

In the remaining two patients, ureterorenoscopy (URS) guided double J stenting was attempted but failed to insert the stent due to stenosed ureter (Figure 4). One of the patient who underwent TAH with BSO, remarkable kinking with adhesions noted in mid ureteric area so left ureterolysis with ureterostomy with DJ stenting was performed in the same setting. The last patient who had involvement of both ureters, landed in obstructive uropathy so initially managed by ultrasound guided percutaneous nephrostomy (PCN) catheter placement. After stabilization of renal function, contrast enhanced CT and DTPA renogram showed nonfunctioning left kidney with wellfunctioning and excreting right kidney. This patient had also undergone TAH with RSO with ureterolysis of right distal and mid ureter with ureterostomy with DJ stenting. In both cases after ureterolysis ureters were free and ureterostomy revealed normal ureteric lumen with easy passage of 6'F' ureteric catheter.

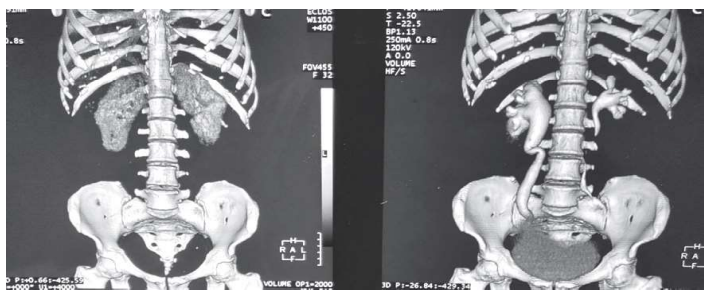

Figure 2: CTU showing Rt distal ureteric stenosis due to endometriosis with moderate hydroureteronephrosis.

In the URS guided double $\mathrm{J}$ insertion group (Table 2), two patients renal function deteriorated after removal of ureteric stents which was confirmed by increasing hydroureteronephrosis on follow up USG scan. Both the patient had moderate to severe hydroureteronephrois on contrast enhanced CT scan (Figure 2 and 3). These two patients finally ended up in ureteric reimplantation. The other two patients, after removal of ureteric stents, are doing fairly good at follow up with no hydronephrosis noted in USG scan. In other two patients with open ureterolysis and ureterostomy and DJ stenting group (Table 2), the success rate is almost $100 \%$ till one and half year of follow up.

Table 2: Follow up with surgical outcome.

\begin{tabular}{|l|l|l|}
\hline Name of procedure & $\begin{array}{l}\text { No of } \\
\text { patients }\end{array}$ & $\begin{array}{l}\text { Success } \\
\text { rate(\%) }\end{array}$ \\
\hline Diagnostic URS and DJ stenting & $4(2+2)$ & $2 / 4=50$ \\
\hline $\begin{array}{l}\text { TAH with excision of chocolate } \\
\text { cyst with ureterolysis and DJ } \\
\text { stenting }\end{array}$ & 2 & 100 \\
\hline $\begin{array}{l}\text { Excision of chocolate cyst with } \\
\text { distal ureteric reimplantation }\end{array}$ & 2 & 100 \\
\hline
\end{tabular}

The post-operative period was uneventful in all the patients. Dienogest (progesterone) $2 \mathrm{mg}$ once daily was used in five patients for the period of three months and in one patient intrauterine levonorgesterol was used. Double J stent were removed after 10 weeks in the open surgery group where as it was removed after 6 months in URS guided DJ insertion group. In all the cases of open surgery histopathology examination of ureteric margins ruled out intrinsic involvement of the affected ureter.

They were evaluated by both urology and gynecology team during the follow up period to rule out recurrence of the disease. All the patients were followed up with ultrasonography of abdomen and pelvis at three months and contrast enhanced study at six months following the removal of DJ stent and yearly ultrasound examination after then. The follow up period ranged from 6 to 35 months. Till date none of the patients have developed stenosis or stricture of ureter at the operated side.

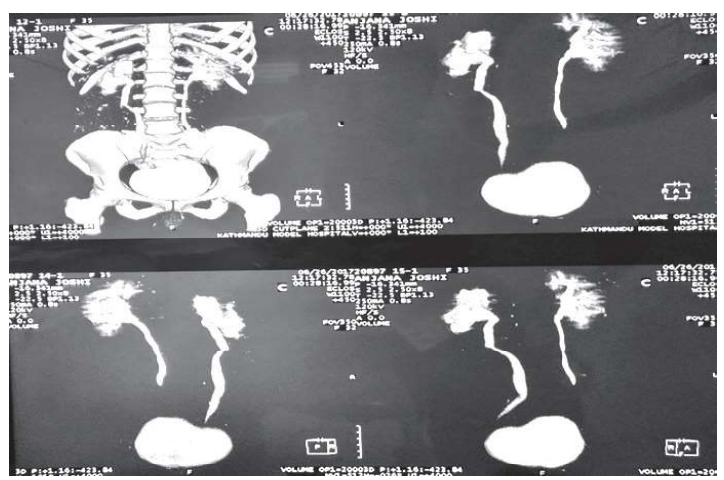

Figure 3: CTU showing Rt distal ureteric stenosis causing moderate hydroureteronephrosis. 


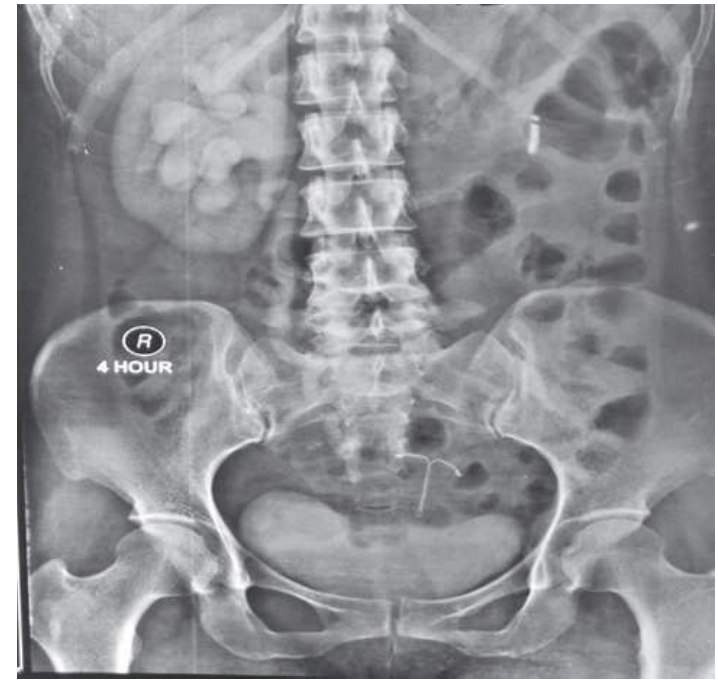

Figure 4: IVU showing nonopacification of left renal system with moderate hydroureteronephrosis due to right distal ureteric stenosis caused by $B / L$ involvement of ureters by endometriosis.

\section{DISCUSSION}

Ureteral endometriosis is a rare disease. It was first described by Cullen in 1917, and it constitutes approximately 0.1 to $0.4 \%$ of urinary tract endometriosis. ${ }^{4}$ Prevalence of endometriosis in urinary system at specific site is as follows: bladder $85-90 \%$, ureter $10 \%$, kidney $4 \%$ and urethra $2 \%{ }^{5}$ Endometriosis occurs when ectopic endometrial cells implant, grow and elicit inflammatory response at a newer site. It also has got multifactorial pathogenesis in which ectopic endometrial tissue, altered immunity, imbalanced cell proliferation and apoptosis, aberrant endocrine signaling and genetic factors. Sampson has also postulated the theory of retrograde menstruation in which he described endometrial cells flow backwards through the fallopian tube and into the peritoneal cavity during menses and cause endometriosis. ${ }^{6}$

Patient with endometriosis usually present during their reproductive years with predominantly the pelvic pain (including dysmenorrhea and dyspareunia), infertility, or an ovarian mass. ${ }^{7}$ Some of the patients are diagnosed incidentally during surgery or imaging scan for other diseases. Additional symptoms include bowel and bladder dysfunction, abnormal uterine bleeding, low back pain, or chronic fatigue. ${ }^{8}$ Majority of the urinary tract endometriosis patients are asymptomatic 50\%. Nearly $25 \%$ present with colicky flank pain and $15 \%$ present with gross hematuria. Some of them also present with non-specific symptoms such as dysmenorrhea and deep dyspareunia. ${ }^{9}$

It's always very much difficult diagnosing endometriosis on the basis of laboratory investigation only. Till present, no pathognomic laboratory tests have been found for the diagnosis of endometriosis. Several urinary and endometrial biomarkers have been studied, but none of them are found to be clinically useful. ${ }^{10}$ Serum CA 125 can be elevated ( $>35$ units/ $\mathrm{ml})$, but its role is still undefined.

Intraoperative findings (open or diagnostic laparoscopy) along with tissue biopsy and histologic confirmation are the gold standard for the diagnosis of endometriosis. Histopathologically endometriotic involvement of the ureter can be classified according to the grade of infiltration of the ureteral wall by the endometriotic tissue which is either intrinsic or extrinsic type. ${ }^{11}$

Intrinsic type involves the ureteric muscle due to the metastasis of ectopic endometrial tissue via lymphatic or venous channel. Mucosal layer is rarely involved in this type and results in fibrosis and proliferation of ureteral muscularis. However, in extrinsic type the endometrial tissue invades the ureteral adventitia and the surrounding connective tissue causing compression of ureteral wall which in turn result in ureteral obstruction and hydronephrosis. ${ }^{11}$ In our series also majority of cases (4 out of 6) who underwent open surgeries had ureteral obstruction due to extrinsic compression of ureter by endometriotic tissue. As explained earlier, there are no specific diagnostic tests for diagnosing endometriosis and it is extremely difficult to estimate the extent of the disease preoperatively. A vaginal ultrasound, abdominal ultrasound, intravenous pyelography (IVP), contrast enhanced CT of abdomen and pelvis along with CT pyelogram, MRI and isotope renography are some of the diagnostic tools used for the preoperative diagnosis and estimating the extent of the disease.

Though contrast enhanced CT pyelogram (CTU) have been widely used in our setup for the estimation of the extent of the disease but in recent year's magnetic resonance imaging (MRI) have been gaining popularity among the clinicians. MRI not only allows assessment of disease extension in the pelvis but also differentiate ureteric involvement. ${ }^{12,13}$ It also allows evaluation of all endometriotic lesions in the abdomen and pelvis and possibly distinguish intrinsic from extrinsic form of ureteral endometriosis and thus helps the clinician in deciding the surgical modality. ${ }^{14}$ In our study, all the 6 patients were evaluated with ultrasonogram of abdomen and pelvis followed by CT Urogram. None of our patients were evaluated by MRI due to cost factor as well as not easy accessibility to MRI. 
Isotope renography should be used selectively in those patients to assess the remaining renal function of the obstructed kidney in case of moderate to severe obstruction. It is reported that $25 \%-50 \%$ of the nephrons are already lost, and almost $30 \%$ of the patients present with reduced kidney function at the time of the diagnosis. ${ }^{15}$ Among our 6 patients, 2 patients underwent isotope renography. One patient had complete loss of left kidney where as the other patient had moderately hydronephrotic right kidney with GFR less than $25 \%$.

Ureteroscopy is helpful in diagnosing intrinsic endometriosis, although negative findings do not exclude the presence of ureteral endometriosis. ${ }^{16} \mathrm{It}$ can also help in diagnosing multifocal lesion and also differentiating other space occupying lesion of the ureter. In our study, diagnostic ureteroscopy attempted in all the cases. In 4 cases extrinsic compression of the distal ureter observed in ureteroscopy with easy passage of ureteric stents. However, in other 2 cases, ureteroscopy examination could not be done due to stenosed lumen of the ureter.

Treatment of ureteral endometriosis is primarily surgical. However, there are many reports of successful medical management by hormonal therapy. Hormonal therapy includes danazol, GnRH agonists (leuprolide, goserelin), medroxyprogesterone, estrogen-progestin combination, and progestin alone. Local progestogens in the form of intrauterine levonorgestrel device has also been used as a longterm hormonal therapy in certain group of patients. It leads to a high concentration of the drug at the endometrium and are effective in the management of pelvic and vesicovaginal septum endometriosis. ${ }^{17}$

Strowitzki et $\mathrm{al}^{18}$ in their study, concluded that dienogest $2 \mathrm{mg}$ /day orally demonstrated equivalent efficacy to depot LA at standard dose in relieving the pain associated with endometriosis, although offering advantages in safety and tolerability. In our short review of 6 cases also, five cases were given dianogest $2 \mathrm{mg}$ orally for a period of twelve weeks and in one patient intrauterine levonogestrel used. Both the drugs were well tolerated by the patients and found to reduce pelvic pain significantly. Follow up ultrasound scan has not shown any evidence of causing obstruction to urinary system in all the patients.

Goals of surgical treatment of ureteral endometriosis is to remove the endometriotic lesion, restore ureteral anatomy and integrity and prevent loss of renal function. The procedures which are usually performed are as follows: excision of all endometriosis lesion, ureterolysis, ureterectomy with ureteroureteral anastomosis and ureteroneocystomy.

Endoscopic treatment (ureteroscopic management) is indicated in patients with intraluminal endometriosis. Ureteroscopy not only allows ablation of endometriotic lesion with laser, but also helps in balloon dilatation with ureteric stent placement. ${ }^{19}$ However, this is often not curative and follow-up imaging, including serial ultrasonogram, retrograde pyelography, ureteroscopic surveillance, is necessary for early detection of disease recurrence and progression.

In our review, 4 out of 6 patients were initially managed by ureteroscopy guided ureteric stent placement. But in 2 patients. after removal of the ureteric stents, degree of ureteric obstruction increased which was confirmed by ultrasound and CT urogram. So these patients finally landed up in ureteroneocystostomy. The other two patients managed by endoscopic method along with hormonal therapy are doing quite well till now with follow up period of 6 to 35 months. They are under regular ultrasonogram surveillance with no evidence of disease recurrence.

In the study done by Kumar et $\mathrm{al}^{20}$, out of nineteen patients, ten had ureteric involvement and nine patients had vesical involvement. Among the patients who had ureteric involvement, success rate of distal ureterectomy and reimplantation was $100 \%$, laparoscopic ureterolysis with double $\mathrm{J}$ stenting followed by injection leuprolide was $75 \%$ while that of Gonadotropin- releasing hormone (GnRh) analogue alone was $67 \%$. A study by Antonelli et $\mathrm{al}^{21}$ concluded that terminal ureterectomy with ureteroneocystostomy has provided long-term favorable results as extended ureteral resection can be performed and continuity of the urinary tract can be maintained. In our review two patients had undergone Rt ureteroneocystostomy along with post-operative hormonal therapy for 12 weeks period. In both the cases the success rate is almost $100 \%$.

Ureterolysis is preferred choice of surgical modality in cases of extrinsic endometriosis with lesions less than $3 \mathrm{~cm}$ and not associated with moderate to severe hydroureteronephrosis compromising renal function. Ureterolysis is a contraindication in intrinsic endometriosis since it is associated with high recurrence rates $(16 \%)$ and ureteral restenosis. ${ }^{22}$ There have been reports of successful management of ureteric endometriosis by laparoscopic technique such as laparoscopic ureterolysis and DJ stenting. Laparoscopic ureterolysis is a minimally invasive technique with low complication and recurrence rates. ${ }^{21,23}$

In our review also two patients had undergone TAH 
with excision of endometriotic cyst along with ureterolysis and DJ stenting. These two patients were also given dianogest $2 \mathrm{mg}$ for a period of twelve weeks postoperatively. The success rate presumed to be $100 \%$ in both the cases till date with regular follow up by ultrasound scan and contrast study at 6 months following removal of ureteric stents.

\section{CONCLUSIONS}

Ureteral endometriosis is a rare disease presenting most commonly with nonspecific symptoms and signs and thus making preoperative diagnosis often difficult for the clinicians. It may eventually lead to significant morbidity and most importantly deterioration of renal function. Treatment of ureteral endometriosis is primarily surgical. Surgical treatment if combined with medical management like hormonal therapy has got excellent results. The surgical procedures which are usually performed are excision of all endometriosis lesion, ureterolysis, ureterectomy with ureteroureteral anastomosis and ureteroneocystomy. Endoscopic treatment (Ureteroscopic management) if combined with medical management also produces excellent result; however strict follow-up imaging is necessary for early detection of disease recurrence and progression.

\section{REFERENCES}

1. Dovey S, Sanfilippo J. Endometriosis and the adolescent. Clin Obstet Gynecol. 2010 Jun;53(2):420-8.

2. Eskenazi B, Warner ML. Epidemiology of endometriosis. Obstet Gynecol Clin North Am. 1997 Jun;24(2):235-8.

3. Reese KA, Reddy S, Rock JA. Endometriosis in an adolescent population: the Emory experience. J Pediatr Adolesc Gynecol. 1996;9(3):125.

4. Cullen TS. Adenomyoma of the tect-vaginal septum. Bull Johns Hopkins Hosp. 1917;28:343.

5. Dénes FT, Pompeo AC, Montelatto NI, Lopes RN. Ureteral endometriosis. Int Urol Nephrol. 1980;12(3):205-9

6. Sampson JA. Peritoneal endometriosis due to the menstrual dissemination of endometrial tissue into the peritoneal cavity. Am J Obstet Gynecol. 1927;14:422.

7. Sinaii N, Plumb K, Cotton L, Lambert A, Kennedy S, Zondervan K, et al. Differences in characteristics among 1,000 women with endometriosis based on extent of disease. 2008;89(3):538. Epub 2007 May 11.

8. Vercellini P, Viganò P, Somigliana E, Fedele L. Endometriosis: pathogenesis and treatment. Nat Rev Endocrinol. 2014 May;10(5):261-75. Epub 2013 Dec 24

9. Comiter CV. Endometriosis of the urinary tract. Urol Clin North Am. 2002;29(3):625

10. Nisenblat V, Prentice L, Bossuyt PM, Farquhar C, Hull ML, Johnson N. Combination of the non-invasive tests for the diagnosis of endometriosisCochrane Database Syst Rev. 2016;7:CD012281. Epub 2016 Jul 13.

11. Yohannes P. Ureteral endometriosis. J Urol. 2003;170:20-5. [PubMed]

12. Kinkel K, Frei KA, Balleyguier C, Chapron C. Diagnosis of endometriosis with imaging: A review. Eur Radiol. 2006;16:285-98. [PubMed]

13. Chapron C, Dubuisson JB. Laparoscopic management of bladder endometriosis. Acta Obstet Gynecol Scand. 1999; 78:887-90. [PubMed]
14. Manyonda IT, Neale EJ, Flynn JT, Osborn DE. Obstructive uropathy from endometriosis after hysterectomy and oophorectomy; two case reports. Eur J Obstet Gynecol Reprod Biol. 1989;31:195-8.[PubMed]

15. Castaneda CV, Shapiro EY, Ahn JJ, Van Batavia JP, Silva MV, Tan Y, et al. Endoscopic management of intraluminal ureteral endometriosis. Urology. 2013;82:307-12. [PubMed

16. Zanetta G, Webb MJ, Segura JW. Ureteral endometriosis diagnosed at ureteroscopy. Obstet Gynecol. 1998;91:857-9. [PubMed]

17. Johnson NP, Hummelshoj L. World Endometriosis Society Montpellier Consortium. Consensus on current management of endometriosis. Hum Reprod. 2013;28:1552-68. [PubMed]

18. T.Strowitzki J. Marr C. Gerlinger T. Faustmann C. Seitz. Human Reproduction, Volume 25, Issue 3, 1 March 2010, Pages 633-641,https://doi.org/10.1093/humrep/dep469

19. Frenna V, Santos L, Ohana E, Bailey C, Wattiez A. Laparoscopic management of ureteral endometriosis: Our experience. J Minim Invasive Gynecol. 2007;14:169-71. [PubMed]

20. Kumar S, Tiwari P, Sharma P, Goel A, Singh JP, Mukesh K. et al. Urinary tract endometriosis: Review of 19 cases. Urol Ann. 2012 Jan-Apr; 4(1): 6-12. doi: [10.4103/0974-7796.91613]

21. Antonelli A, Simeone C, Frego E, Minini G, Bianchi U, Cunico SC. Surgical treatment of ureteral obstruction from endometriosis: our experience with thirteen cases. Int Urogynecol J Pelvic Floor Dysfunct. 2004 NovDec;15(6):407-12; discussion 412. Epub 2004 Jul 31

22. Pérez-Utrilla Pérez M, Aguilera Bazán A, Alonso Dorrego JM, Hernández A, de Francisco MG, Martín Hernández M, et al. Urinary tract endometriosis: Clinical, diagnostic, and therapeutic aspects. Urology. 2009;73:47-51. [PubMed]

23. Talreja D, Salunke V, Pande S, Gupta C. Successful management of ureteric endometriosis by laparoscopic ureterolysis - A review and report of three further cases. Arab J Urol. 2018 May 31;16(3):342-349. doi: 10.1016/j. aju.2018.03.001. eCollection 2018 Sep. 